Article

\title{
Apoptotic Induction and Anti-Migratory Effects of Rhazya Stricta Fruit Extracts on a Human Breast Cancer Cell Line
}

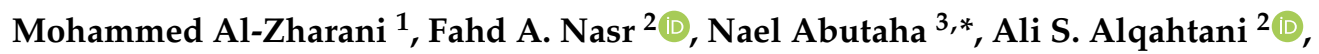 \\ Omar M. Noman ${ }^{2}$ (D), Mohammed Mubarak ${ }^{4}$ and Muhammad A. Wadaan ${ }^{3}$ \\ 1 Imam Mohammad Ibn Saud Islamic University (IMSIU), College of Science, Biology Department, \\ Riyadh 11623, Saudi Arabia; MMyAlzahrani@Imamu.edu.sa \\ 2 Medicinal Aromatic, and Poisonous Plants Research Centre, College of Pharmacy, King Saud University, \\ Riyadh 11451, Saudi Arabia; fnasr@ksu.edu.sa (F.A.N.), alalqahtani@ksu.edu.sa (A.S.A.), \\ onoman@ksu.edu.sa (O.M.N.) \\ 3 Bioproducts Research Chair, Department of Zoology, College of Science, King Saud University, \\ Riyadh 11451, Saudi Arabia; wadaan@ksu.edu.sa \\ 4 Electron Microscope Unit, King Saud University Medical City, Riyadh 11451, Saudi Arabia; \\ mohammedahmed_62@yahoo.com \\ * Correspondence: nabutaha@ksu.edu.sa
}

Academic Editor: Luisa Tesoriere

Received: 30 September 2019; Accepted: 28 October 2019; Published: 1 November 2019

\begin{abstract}
Rhazya stricta is a medicinal plant that is widely used in Saudi folklore medicine for treatment of various diseases. $R$. stricta fruit powder was sequentially extracted with $n$-hexane, chloroform, ethyl acetate, and methanol using a Soxhlet extractor. The cytotoxic effects of these fractions on human breast cancer cells (MDA-MB-231 and MCF-7) and non-tumorigenic control cells (MCF-10A) were evaluated via cell viability measurements, microscopy, gene expression, and migration assays. Moreover, the effect of the most promising extract on 7,12-dimethyl-benz[a]anthracene (DMBA)-induced breast cancer was investigated in rats. The promising extract was also subjected to gas chromatography-mass spectrometry. Fruit extracts of $R$. stricta were significantly cytotoxic toward all tested cell lines, as demonstrated by MTT and LDH assays. Treatment of MDA-MB-231 cells with fruit ethyl acetate fraction (RSF EtOAc) increased expression 11of P53, Bax and activation of caspase 3/7. A cell migration scratch assay demonstrated that extracts at non-cytotoxic concentrations exerted a potent anti-migration activity against the highly invasive MDA-MB-231 cell line. Moreover, RT-PCR results showed that RSF EtOAc significantly downregulated MMP-2 and MMP-9 expression, which play an important role in breast cancer metastasis. Histological studies of breast tissue in experimental animals showed a slight improvement in tissue treated with fruit ethyl acetate extract. GC-MS chromatogram showed thirteen peaks with major constituents were camphor, trichosenic acid and guanidine. Our current study demonstrates that fruit extracts of $R$. stricta are cytotoxic toward breast cancer cell lines through apoptotic mechanisms.
\end{abstract}

Keywords: Rhazya stricta; breast cancer; cell migration; apoptosis; GC-MS

\section{Introduction}

Globally, breast cancer is the second most common cancer after lung cancer. It is a major public health issue and is the leading cause of cancer death in women [1], with an estimated 522,000 deaths and 1.7 million new cases reported worldwide in 2012 alone [2]. In Saudi Arabia, breast cancer is the leading cause of cancer death [3] with an estimated 1856 new cases in 2014 according to the Saudi cancer incidence report [4]. Cancer cells can develop resistance to anticancer drugs through different 
mechanisms such as drug efflux, cell death inhibition, epithelial-mesenchymal transition, drug target alteration, DNA damage repair, and epigenetic modifications. More than $50 \%$ of patients experience cancer relapse and die from acquired resistance [5].

Many currently used anti-cancer drugs, such as the taxanes, become ineffective for breast cancer treatment because of acquired resistance to the treatment [6]. Therefore, this necessitates the search for new therapeutic agents to overcome acquired resistance in endocrine-resistant patients.

In recent years, use of plants in primary health care and phytotherapeutic research has increased owing to identification of bioactive molecules in medicinal plants and growing interest in alternative medicines. According to the World Health Organization (WHO), 80\% of people rely on plant-based traditional medicines for primary health care [7]. Over $50 \%$ of anticancer drugs used in clinical trials have been isolated from plant-based natural sources [8].

Rhazya stricta Decne (locally known as harmal) is a medicinal plant belonging to the Apocynaceae family and has been traditionally used for treating various diseases in many Middle East and South Asian countries. R. stricta is used for treatment of various disorders such as diabetes, stomach disorders, and intestinal illness. It is also used as a purgative, antihelminthic, antipyretic, and anti-inflammatory medicine, and to treat sore throats and chronic rheumatism [9]. Many compounds isolated from $R$. stricta have proven to be antineoplastic (16-epi-(Z)-isositsirkine), antimicrobial (akuammidine, rhazimine, stemmadenine, tetrahydrosecaminediol) and cytotoxic (didemethoxycarbonyltetrahydrosecamine, sewarine, tetrahydrosecamine, tetrahydrosecaminediol diacetate, vallesiachotamine, and D,L-1-(oxo-3,4-thero-3,4,5-trihydroxy-1-pentyl)- $\beta$-carboline) [9].

Previously, several studies investigated anti-proliferation activity of $R$. stricta extracts against different cancer cells [10-12]. However, our study is the first to evaluate $R$. stricta fruit extracts in an animal model (in vivo) and investigate the anti-migratory activity against the highly aggressive, invasive, and triple-negative (ER, PR and HER2 negative) MDA-MB-231 breast cancer cells (in vitro). Moreover, the effects of different fractions of $R$. stricta from fruit part on cytotoxicity of non-metastatic MCF-7 breast cancer (ER/PR positive) cells, and non-tumorigenic MCF-10A cells were assessed.

\section{Results}

\subsection{Cytotoxic Activity of Rhazya stricta Fruit Extracts Against Breast Human Cancer Cell Lines}

Chloroform and ethyl acetate extracts displayed the strongest cytotoxicity against MCF-7 and MDA-MB-231 breast cancer cell lines compared to hexane and methanol extracts. The normal MCF-10A showed sensitivity to nearly all extracts. The fruit ethyl acetate (RSF EtOAc) and chloroform (RSF CHCL 3 ) fractions inhibited MDA-MB-231 cells with $\mathrm{IC}_{50}$ values of 27 and $56 \mu \mathrm{g} / \mathrm{mL}$, respectively. The two fractions also showed strong activity against MCF-7 cells ( $\mathrm{IC}_{50}=39$ and $49 \mu \mathrm{g} / \mathrm{mL}$, respectively). The other fractions exhibited different $\mathrm{IC}_{50}$ values (Table 1). Cell death after treatment was also determined by release of LDH into the incubation medium. Significant LDH release because of decreased membrane integrity in treated MCF-7 and MDA-MB-231 cells was observed after $48 \mathrm{~h}$ of treatment (Figure 1).

Table 1. Comparison of $\mathrm{IC}_{50}$ values for the different $R$. stricta fruit fractions towards MCF-7, MDA-MB-231 and MCF-10A breast cancer cell lines.

\begin{tabular}{cccc}
\hline \multirow{2}{*}{ Fraction Abbrev. } & \multicolumn{3}{c}{ Cell Lines and IC $_{50}(\mu \mathrm{g} / \mathrm{mL})$} \\
\cline { 2 - 4 } & MCF-7 & MDA-MB-231 & MCF-10A \\
\hline RSF Hex & $104 \pm 2.1$ & $167 \pm 1.4$ & $168 \pm 1.4$ \\
\hline RSF CHCL $_{3}$ & $49 \pm 1.1$ & $56 \pm 0.6$ & $49 \pm 1.1$ \\
\hline RSF EtOAc & $39 \pm 0.8$ & $27 \pm 0.5$ & $47 \pm 0.9$ \\
\hline RSF MeOH & $160 \pm 1.5$ & $177 \pm 2.2$ & $193 \pm 0.6$ \\
\hline
\end{tabular}


(A)
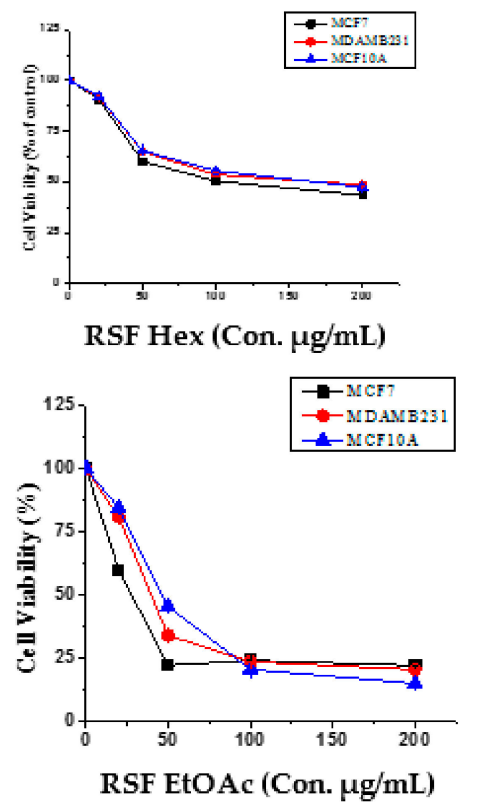

(B)

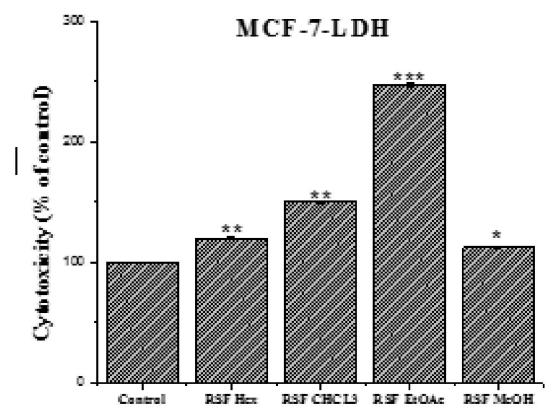

Fractions (ICso)

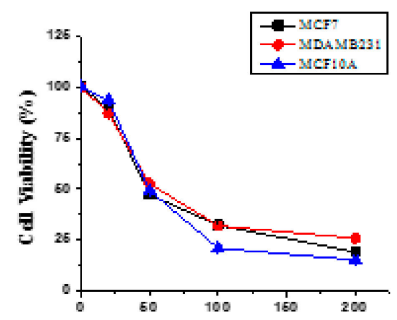

RSF CHCL3 (Con. $\mu \mathrm{g} / \mathrm{mL}$ )
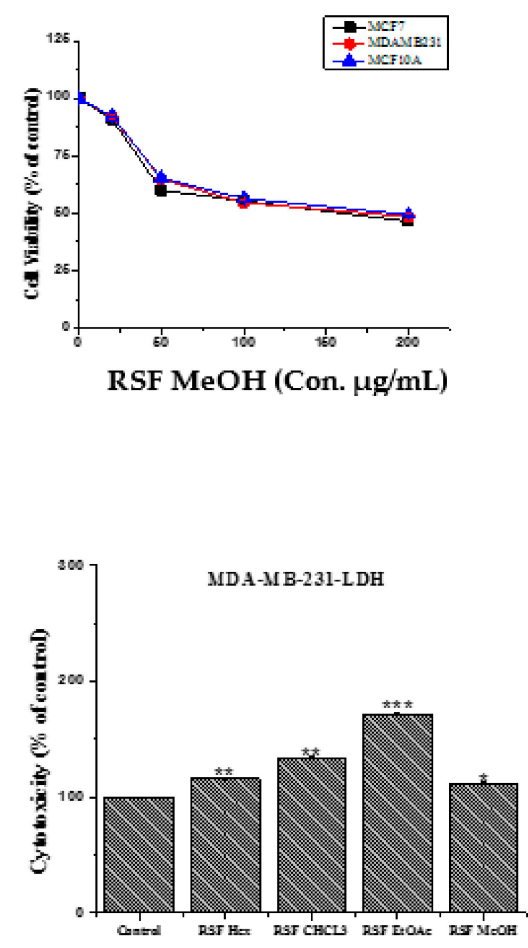

Fractions (ICso)

Figure 1. Cytotoxic effects of $R$. stricta Fruit fractions on human breast cancer cells. (A) Dose-dependent curves of different extract treatments. Cells were cultured in 24-well plates and treated with different concentrations (10-200 $\mu \mathrm{g} / \mathrm{mL})$ for $48 \mathrm{~h}$. Cell viability was measured by MTT assay. (B) MCF-7, MDA-MB-231 and MCF-10A were treated at $\mathrm{IC}_{50}$ for $48 \mathrm{~h}$. LDH released into media was determined at $490 \mathrm{~nm}$ using a microplate reader. Statistical differences were analyzed using Student's $t$-test. Data are presented as mean \pm S.D. $\left({ }^{*} p<0.05,{ }^{* *} p<0.01,{ }^{* * *} p<0.001\right.$ was considered significant compared to control) of three independent experiments.

\subsection{Apoptotic Activity of RSF EtOAc}

The fruit ethyl acetate extracts (RSF EtOAc) of $R$. stricta exhibited the highest cytotoxic activity compared to other extracts at $\mathrm{IC}_{50}$. As such, this extract was further evaluated for apoptotic activity.

\subsubsection{Microscopic Studies}

Morphological changes of MCF-7 and MDA-MB-231 after $48 \mathrm{~h}$ of exposure to RSF EtOAc were observed using an inverted light microscope. A high-density monolayer of cells with intact membranes was observed in untreated cells. In contrast, treated cells showed reduced cell volume after treatment at $\mathrm{IC}_{50}$. Nuclear features of apoptosis were clearly observed after $48 \mathrm{~h}$ of treatment (Figure 2). 


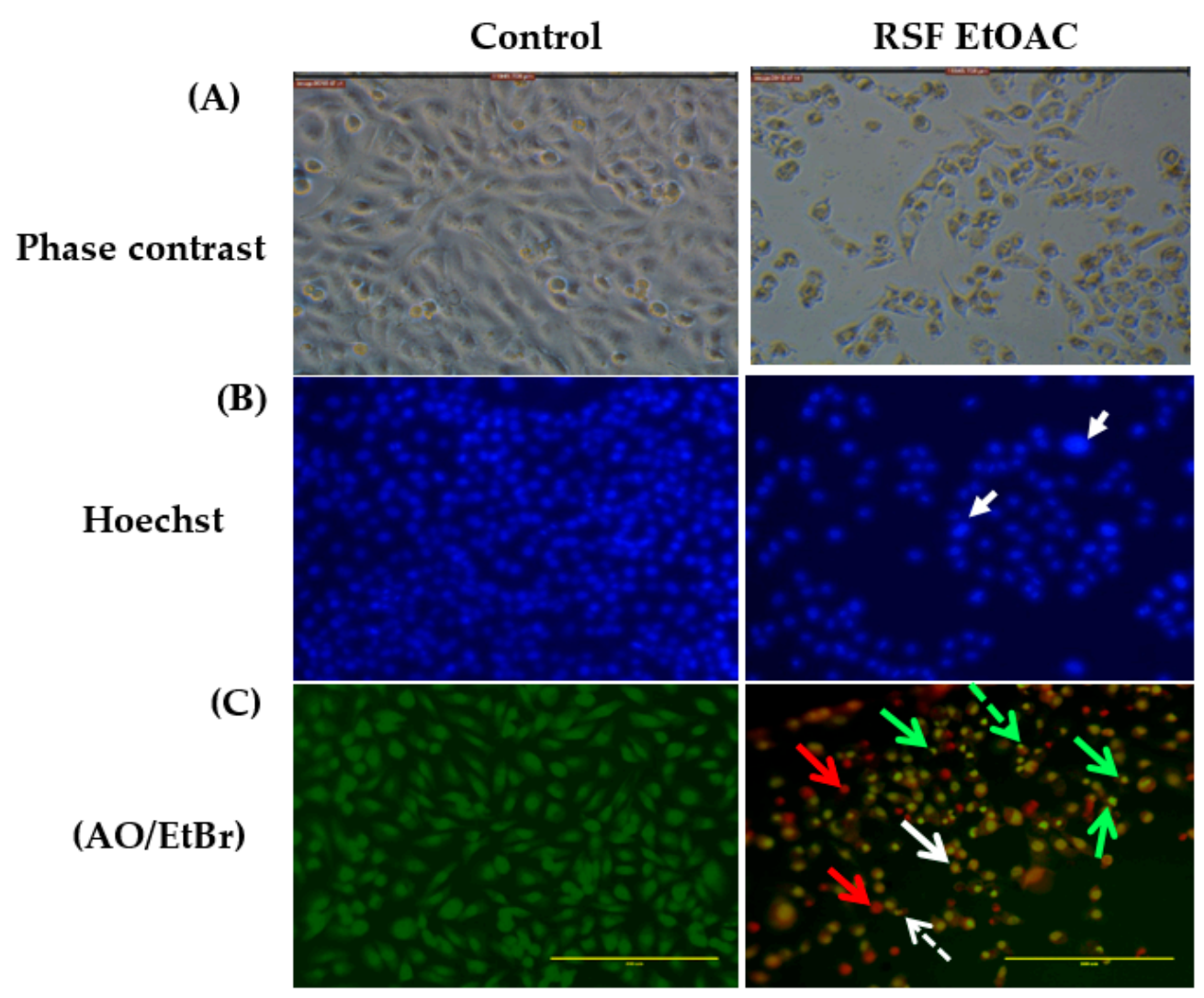

Figure 2. Detection of apoptosis in MDA-MB-231 cells after treatment with $\mathrm{IC}_{50}$ RSF EtOAC extract. (A) Phase-contrast microscopy showed a significant decrease in the number of cells after treatment versus untreated cells. (B) Nuclear morphology changes in both control and treated cells assessed by Hoechst staining, arrows indicating apoptotic cells (C) Viable cells show green fluorescence while necrotic and apoptotic cells show orange and yellow fluorescence. A dotted arrow indicates fragmented nuclei, a regular arrow indicates membrane blebbing, a green arrow represents apoptotic cells, and a red arrow represents necrotic cells.

The results of acridine orange (AO) and ethidium bromide (EB) staining of MDA-MB-231 cells treated with RSF EtOAc extract are shown in Figure 2. AO is a fluorescent dye that stains DNA of live and dead cells, whereas EB is a fluorescent dye that stains DNA of cells that have lost membrane integrity [13].

After AO/EB staining viable cells were equally stained in green, early apoptotic cells were stained green/yellow, late apoptotic cells were stained yellow/orange with dots of condensed nuclei, and necrotic cells exhibited red fluorescent nuclei with no chromatin fragmentation (Figure 2).

\subsubsection{RT-PCR}

To determine mRNA expression levels of apoptosis-related genes, we performed RT-PCR. After $24 \mathrm{~h}$ treatment of MDA-MB-231 cells with RSF EtOAc at IC 50 , p53, Bax, caspase 9, and caspase 3 mRNA band intensity increased 5.89-, 7.5-, 7.72-, and 3-fold, respectively (Figure 3). To confirm apoptosis, the commercial kit CellEvent ${ }^{\mathrm{TM}}$ Caspase- $3 / 7$ detection was used to assess caspase- 3 and -7 activity using fluorescence microscopy. 
(A)

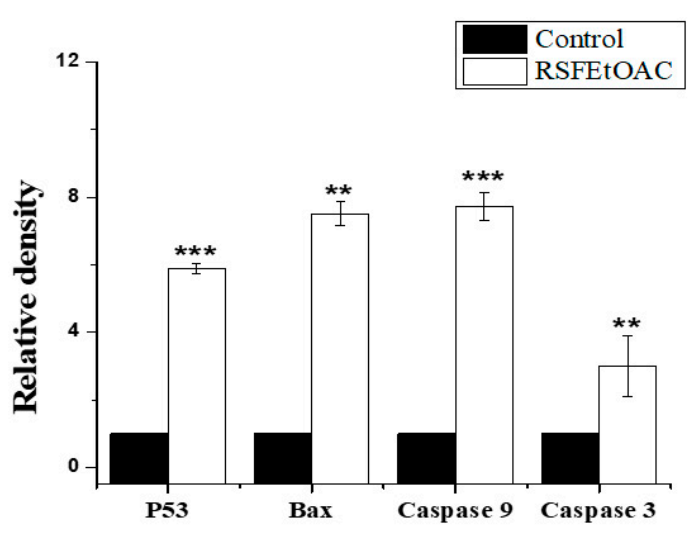

(B)

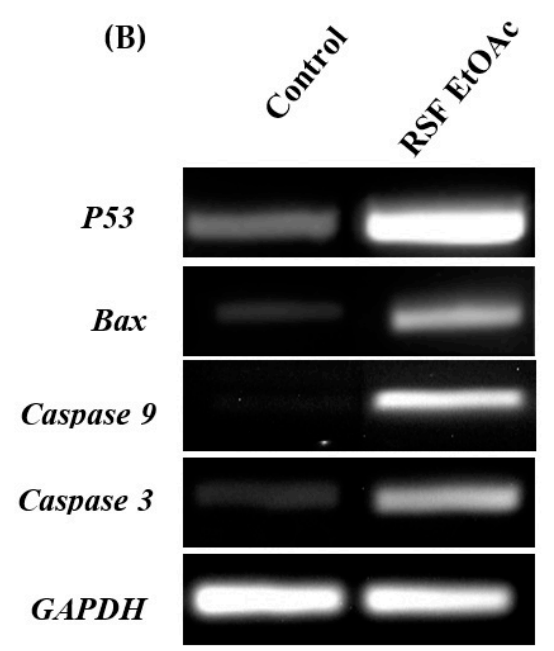

Figure 3. Effect of RSF EtOAc extract on P53, Bax, caspase-9 and caspase-3 mRNA levels in MDA-MB-231 cells. (A) The relative density variation of mRNA levels found in MDA-MB-231 treated at $\mathrm{IC}_{50}$ compared with control. (B) Ethidium bromide-agarose gel showing P53, Bax, and caspases 3 and 9 mRNA levels: Lane 1) Vehicle control, Lane 2) RSF EtOAc extract treated. Results are expressed as mean \pm SD ( $n=3)$. Statistical significance was assessed using Student's t-test. Relative mRNA level was normalized to GAPDH mRNA level. ${ }^{*} p<0.05 ;{ }^{* *} p<0.01 ;{ }^{* * *} p<0.001$ treatment group vs. control group.

As shown in Figure 4, MDA-MB-231 cells showed significant activation of caspase-3 and -7 after $24 \mathrm{~h}$ of treatment.

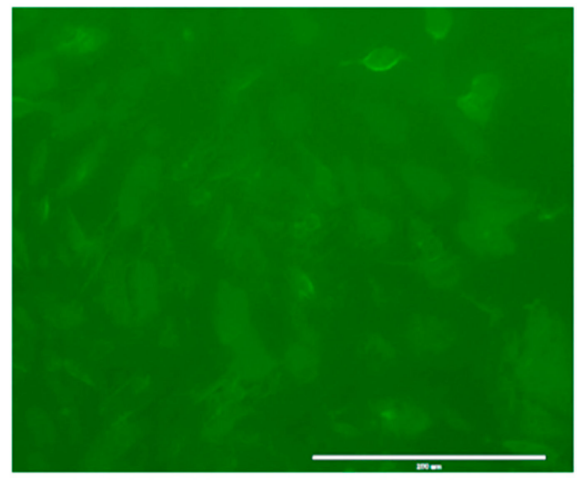

Control

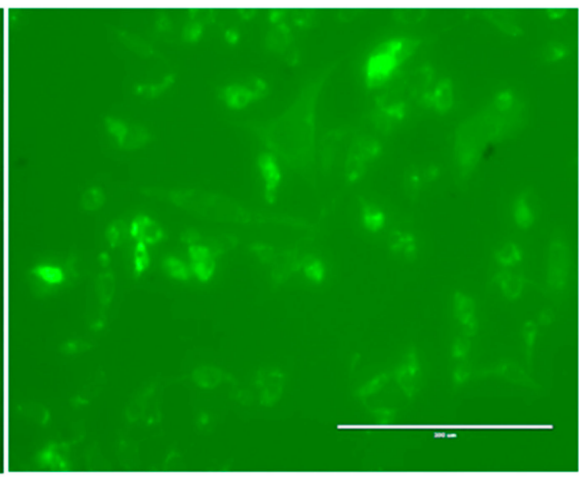

RSF EtOAc ( $\left.\mathrm{IC}_{50}\right)$

Figure 4. Activation of caspase-3 and 7 in MDA-MB-231 cells. Cells were treated with vehicle and at $\mathrm{IC}_{50}$ for $24 \mathrm{~h}$. Activated caspase-3/7 was visualized by fluorescence microscopy. (RSF EtOAc) R. stricta fruit ethyl acetate extract was used.

\subsection{Effects of RSF EtOAc on Cell Migrations of MDA-MB-231}

To determine whether RSF EtOAC extract inhibits the migration of the highly metastatic cell, MDA-MB-231, in vitro wound-healing assay was performed. A non-cytotoxic concentration $\left(1 / 2 \mathrm{IC}_{50}\right)$ of RSF EtOAc fraction was used to assess MDA-MB-231 migration. After $48 \mathrm{~h}$, control MDA-MB-231 cells had migrated into the scratched area, whereas RSF EtOAc-treated cells migrated significantly less $(p<0.05,48 \mathrm{~h})$ (Figure 5). 
(A)

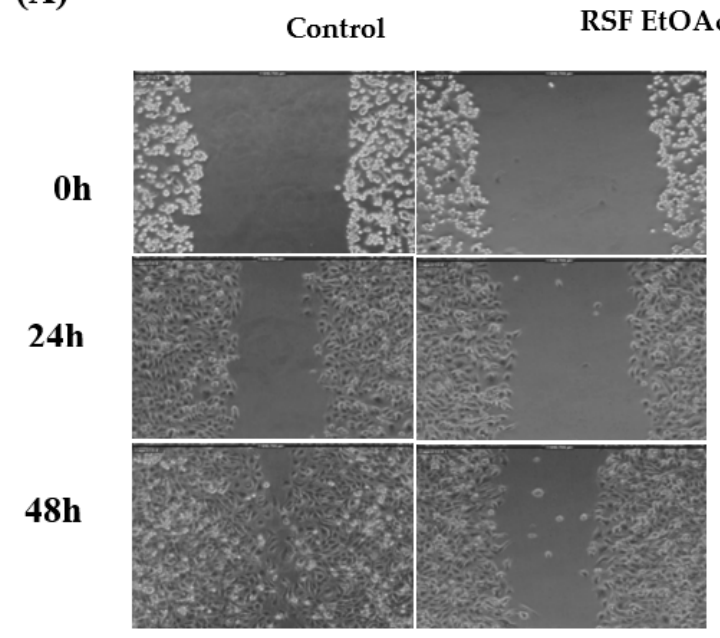

(B)

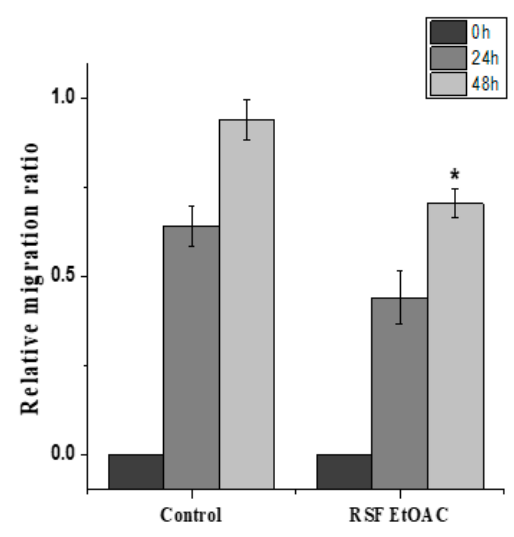

Figure 5. Effects of RSF EtOAC on MDA-MB-231 cell migration. (A) Images of the wounded monolayer of MDA-MB-231 cells captured immediately after wounding $(t=0 \mathrm{~h})$ and following an incubation time of $24 \mathrm{~h}$ or $48 \mathrm{~h}$. Cells were untreated (control) or treated at $\mathrm{IC}_{25}$. (B) Cell migration rate was calculated as described in materials and method. Experiments were performed in triplicate, ${ }^{*} p<0.05,{ }^{* *} p<0.01$ vs. the control (Student's two-tailed $t$-test).

To explore the mechanism by which RSF EtOAC inhibits migration of MDA-MB-231 cells, RNA levels of matrix metalloproteinase (MMP-2 and -9) were evaluated by RT-PCR. Our results indicated that RSF EtOAc extract at $\mathrm{IC}_{50}$ suppressed mRNA expression of mRNA of MMP-2 and -9 compared to controls (Figure 6).

(A)

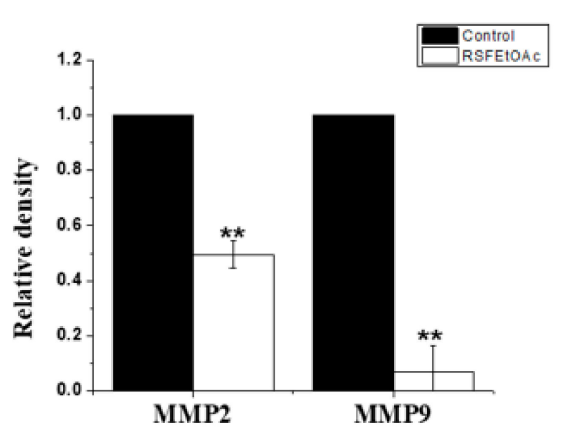

(B)

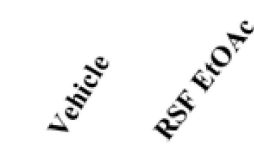

MMP 2

MMP 9

GAPDH

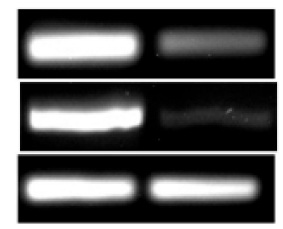

Figure 6. Effect of RSF EtOAc extract on expression of MMP-2 and MMP9 in MDA-MB-231 breast cancer cells. (A) The relative density variation of mRNA levels found in MDA-MB-231 treated at $\mathrm{IC}_{50}$ when compared with control. (B) Ethidium bromide-agarose gel showing MMP2 and MMP9 mRNA levels: Lane 1) Vehicle control, Lane 2) extract treated. Results are expressed as mean \pm SD $(n=3)$. Statistical significance was assessed by Student's $t$-test. Relative mRNA level was normalized to GAPDH mRNA level. ${ }^{*} p<0.05 ;{ }^{* *} p<0.01$; treatment group vs. control group.

\subsection{Histopathology and Morphological Observations}

The fruit ethyl acetate extract (RSF EtOAc) of $R$. stricta was also chosen to evaluate in vivo in a DMBA-induced mammary tumorigenesis model. Immediately following DMBA injection animals were healthy and did not exhibit behavioral changes. Tumors were mostly observed after eight weeks. The tumor size was not significantly reduced after treatment with RSF EtOAc extract compared to control group. An average tumor volume of $1019 \mathrm{~mm}^{3}$ was calculated in control group, while upon RSF EtOAc extract injection, the average tumor volume was $1008 \mathrm{~mm}^{3}$ (Figure 7). 
(A)

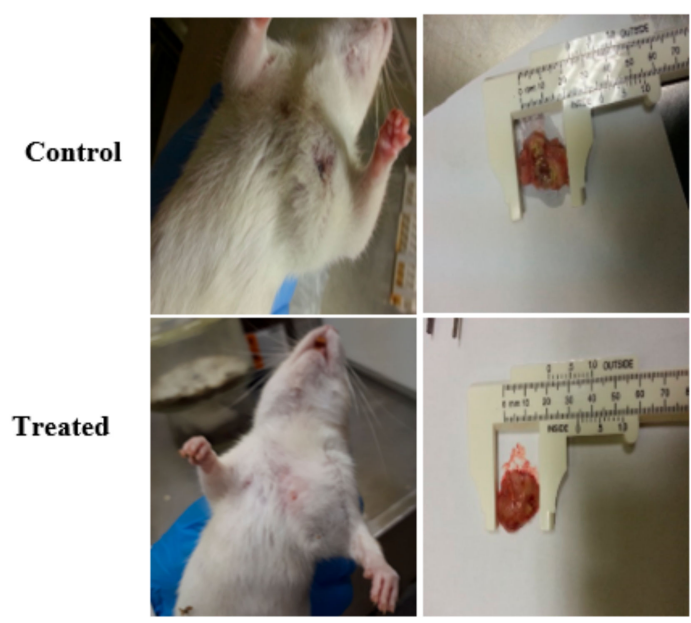

(B)

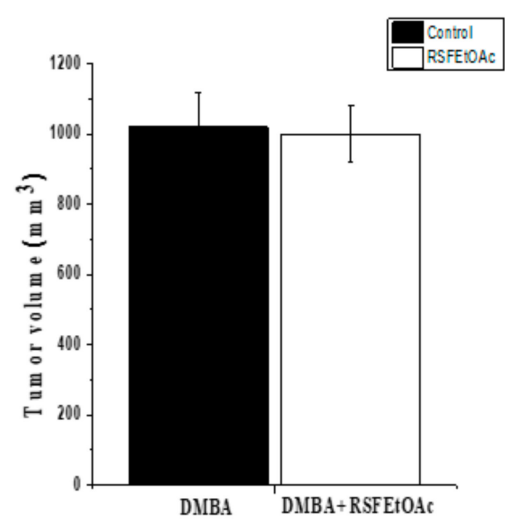

Figure 7. Breast cancer induced in Wistar albino rats (Rattus norvegicus) by subcutaneous injection of 9,10-dimethylbenz [a] anthracene (DMBA). (A) Tumor images in control (DMBA group) and after injection with RSF EtOAc extract and the size of excised tumors formed. (B) tumor volume in control and treated groups was calculated as described in materials and methods.

Histological examination of mammary gland tissue of control rats showed normal morphology of the ductular structures, which were surrounded by a small amount of fibrous connective tissue and adipose tissue (Figure 8A).
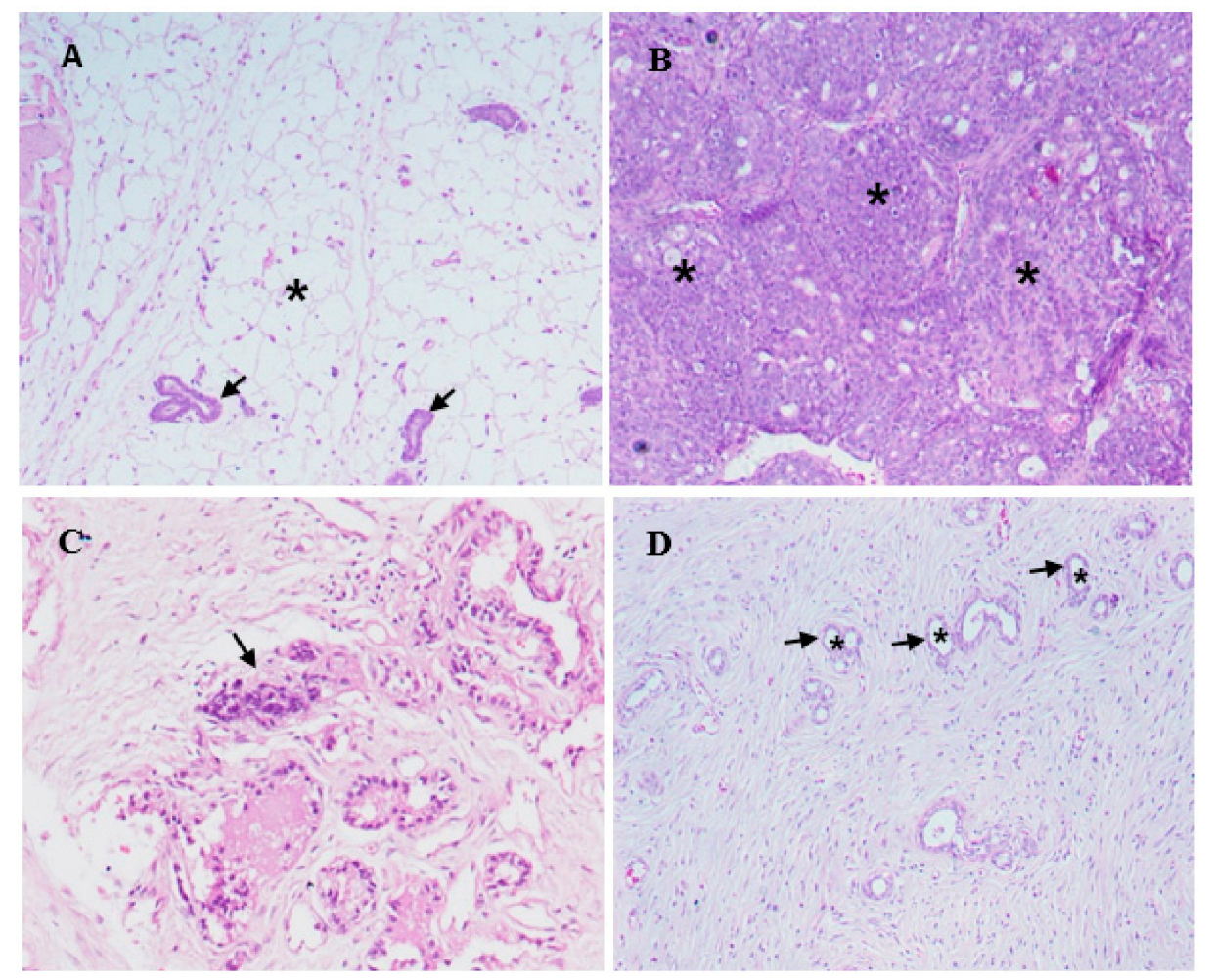

Figure 8. Light micrographs showing mammary gland tissues in control rats, DMBA-injected rats, and DMBA-injected rats treated with RSF EtOAc extract (A) Structure of mammary gland tissue in a control rat. Arrows indicate ducts and epithelial lining cells. Adipose tissue $\left(^{*}\right)$ surrounds the ducts (B) Mammary gland tissue of DMBA-injected rat showing markedly proliferating neoplastic ductal epithelial cells $(*)$ obliterating the ductal lumina (C) Area of necrosis (arrow) in the mammary gland tissue of DMBA-injected 
rat, nuclear and cytoplasmic debris is seen in the area of necrosis (D) Mammary gland tissue of a DMBA-injected rat treated with RSF EtOAc extract. The ductal epithelial lining cells (arrows) are not proliferated and ductal lumina $\left(^{*}\right)$ are patent.

In mammary gland tissues of DMBA-injected rats, the ductal epithelial lining cells showed neoplastic changes identified as ductal carcinoma. Lining epithelial cells had markedly proliferated and appeared as densely packed cell layers that caused narrowing and even obstruction of the ductal lumina (Figure 8B). The proliferated neoplastic cells had pleomorphic nuclei varying in shape and size and had prominent nucleoli. Ductal cellular proliferation was so extensive in some areas of the mammary gland tissue that the histological architecture and organization was obscured. Large numbers of neoplastic cells were also found infiltrating the interstitial tissue. Scattered areas of necrosis of various sizes were observed, and the necrotizing process mainly involved the ductal elements of the mammary gland tissue (Figure 8C). No comparable histological changes were noticed in DMBA-injected rats that were treated with RSF EtOAc extract. Mammary gland tissue in this group showed no recognizable neoplastic proliferating cells in most of the examined ductal structures. In addition, no noticeable areas of necrosis were detected in the examined tissues of rats in this group (Figure 8).

\subsection{Quantitative Phytochemical of R. stricta Fruit}

Total phenol and flavonoid contents of $R$. stricta fruit fractions were quantified using gallic acid and quercetin standard curves (the standard curve equation: $y=0.0005 \times x+0.0505, R^{2}=0.997$ and $\mathrm{y}=0.0052 \times \mathrm{x}+0.1576, \mathrm{r} 2=0.996$ respectively). Total phenol concentration is reported in $\mu \mathrm{g} / \mathrm{mL}$ of extract, with results ranging from 220 to $257 \mu \mathrm{g} / \mathrm{mL}$ (Table 2). The concentration of flavonoids in fractions ranged from 40 to $75 \mu \mathrm{g} / \mathrm{mL}$. RSF EtOAc fraction had the highest phenol and flavonoid content (Table 2). Antioxidant activities of fractions are represented in terms of percentage of scavenging activity of DPPH (\%). The strongest antioxidant activity was observed in RSF EtOAc with a value of $51.81 \%$ (Table 2 ).

Table 2. Phenolic, flavonoid contents and radical scavenging activity of $R$. stricta fruit fractions.

\begin{tabular}{cccc}
\hline Fraction & Total Phenolics $(\mu \mathrm{g} / \mathrm{g})$ & Total Flavonoid $(\mu \mathrm{g} / \mathrm{g})$ & Antioxidant $(\%)$ \\
\hline RSF Hex & $235 \pm 2.5$ & $55.63 \pm 1.1$ & $44.25 \pm 1.8$ \\
\hline RSF CHCL 3 & $246.67 \pm 3.4$ & $47.89 \pm 2.3$ & $37.66 \pm 2.5$ \\
\hline RSF EtOAc & $257 \pm 1.5$ & $75 \pm 2.5$ & $51.81 \pm 1.6$ \\
\hline RSF MeOH & $220 \pm 1.7$ & $40 \pm 1.5$ & $41.41 \pm 2.1$ \\
\hline
\end{tabular}

\subsection{Gas Chromatography Mass Spectroscopy}

GC-MS chromatogram analysis of the RSF EtOAc fraction showed thirteen peaks (Figure 9) which showing the presence of thirteen compounds (Table 3).

Table 3. Compounds identified in the ethyl acetate fraction of R. stricta using GC-MS.

\begin{tabular}{ccccccc}
\hline Compound Name & Chemical Formula & Molecular Weight (g/mol) & RT (min) & Area & Area $\%$ \\
\hline Phenylacetaldehyde & $\mathrm{C}_{8} \mathrm{H}_{8} \mathrm{O}$ & 120.15 & 9.18 & 257603 & 8.040 \\
\hline (Dimethylamino)methylene malononitrile & $\mathrm{C}_{6} \mathrm{H}_{7} \mathrm{~N}_{3}$ & 121.140 & 9.70 & 37370 & 1.170 \\
\hline trans-2-Undecenal & $\mathrm{C}_{11} \mathrm{H}_{20} \mathrm{O}$ & 168.28 & 13.22 & 103901 & 3.240 \\
\hline Dihydrocitronellal & $\mathrm{C}_{10} \mathrm{H}_{20} \mathrm{O}$ & 156.27 & 14.10 & 64583 & 2.010 \\
\hline Linalyl butyrate & $\mathrm{C}_{14} \mathrm{H}_{24} \mathrm{O}_{2}$ & 224.344 & 16.90 & 136684 & 4.260 \\
\hline D-Allose & $\mathrm{C}_{6} \mathrm{H}_{12} \mathrm{O}_{6}$ & 180.156 & 17.95 & 230986 & 7.200 \\
\hline 1-(3,4-Dimethoxyphenyl) ethanone & $\mathrm{C}_{10} \mathrm{H}_{12} \mathrm{O}_{3}$ & 180.203 & 19.06 & 178135 & 5.560 \\
\hline 2,2-Tricosenoic acid & $\mathrm{C}_{23} \mathrm{H}_{44} \mathrm{O}_{2}$ & 352.603 & 27.46 & 484030 & 15.100 \\
\hline 9-Octadecenoic acid & $\mathrm{C}_{18} \mathrm{H}_{34} \mathrm{O}_{2}$ & 282.468 & 27.70 & 64120 & 2.000 \\
\hline
\end{tabular}


Table 3. Cont.

\begin{tabular}{cccccc}
\hline Compound Name & Chemical Formula & Molecular Weight (g/mol) & RT (min) & Area & Area \% \\
\hline Aspidospermine & $\mathrm{C}_{22} \mathrm{H}_{30} \mathrm{~N}_{2} \mathrm{O}_{2}$ & 354.494 & 28.74 & 240055 & 7.490 \\
\hline Quebrachamine & $\mathrm{C}_{19} \mathrm{H}_{26} \mathrm{~N}_{2}$ & 282.431 & 31.64 & 211407 & 6.590 \\
\hline Camphor & $\mathrm{C}_{10} \mathrm{H}_{16} \mathrm{O}$ & 152.23 & 32.19 & 675960 & 21.080 \\
\hline Guanidine & $\mathrm{CH}_{5} \mathrm{~N}_{3}$ & 59.07 & 34.76 & 465365 & 14.520 \\
\hline
\end{tabular}

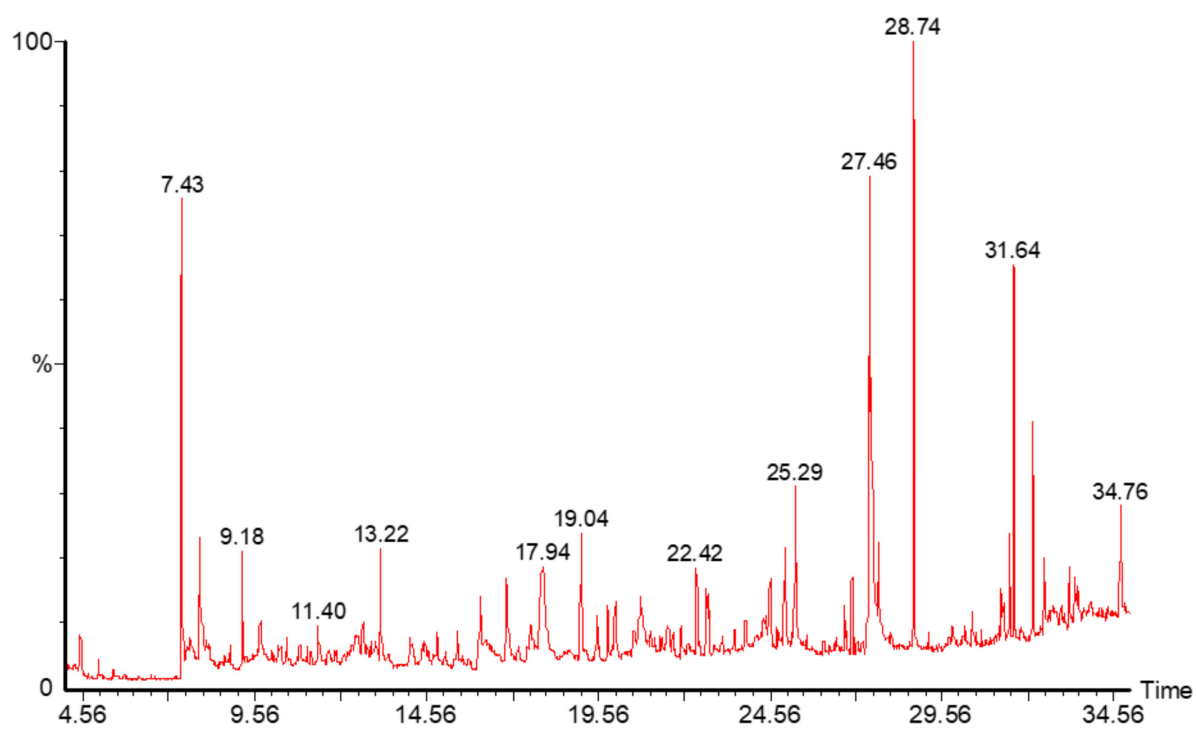

Figure 9. GC-MS analysis of phytochemical compounds in RSF EtOAc extract.

The GC-MS chromatogram and peak area of separation of the components are shown in (Figure 9). The major compounds were camphor (21\%), trichosenic acid (15\%), guanidine (14\%) and phenyl acetaldehyde (8\%) (Figure 10).

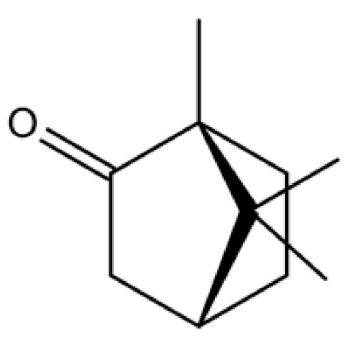

Camphor<smiles>O=CCc1ccccc1</smiles>

Phenyl<smiles>NC(N)=NO</smiles>

Guanidine

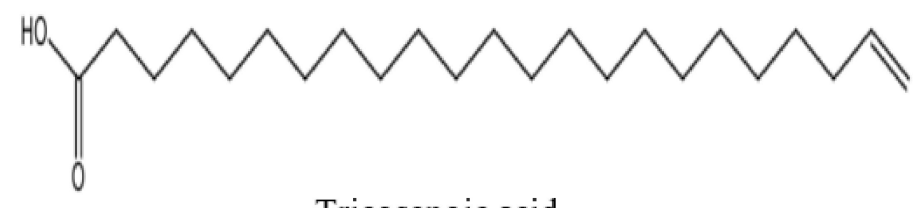

Tricosenoic acid

Figure 10. Major constituents in RSF EtOAc extract. 


\section{Discussion}

In this study, fractions of $R$. stricta fruit were screened for their ability to induce cytotoxicity, apoptosis, and anti-migration activity in estrogen-positive (MCF-7), estrogen-negative (MDA-MB-231), and normal (MCF-10A) human breast cancer cell lines. To obtain a maximum amount and diversity of biologically active phytochemicals, we performed these extractions using solvents with varying polarity. All extracts exhibited anti-proliferative activity in a dose-dependent manner. However, our results revealed that the most promising extract was $R$. stricta fruit ethyl acetate extract (RSF EtOAc), which had an $\mathrm{IC}_{50}$ value $27 \mu \mathrm{g} / \mathrm{mL}$ in the MDA-MB-231 cell line. According to the American National Cancer Institute the $\mathrm{IC}_{50}$ value of a crude extract is considered promising if it is lower than $30 \mu \mathrm{g} / \mathrm{mL}$ [14]. RSF EtOAc fraction may be promising for use as anticancer treatments. Our results were consistent with the findings of Baeshen et al. [10], who reported that aqueous and ethanol extracts of $R$. stricta had anti-proliferative effects in both MCF-7 and MDA-MB-231 cells. Comparing $\mathrm{IC}_{50}$ values, our results showed higher activity of the extracts compared to their results, which may be attributed to the type of solvents and methods of extractions used.

The R. stricta was also cytotoxic to the MCF-10A cells (non-tumorigenic cells) which indicates the non-selective inhibition of cancer cell growth however, further investigation on fractionation of the extract might improve the cytotoxicity and selectivity.

The ability of RSF EtOAc extract to induce cell death was examined to clarify the mechanism by which these extracts inhibited cell growth. The inhibitory activity of $R$. stricta fractions on cell growth was associated with induction of apoptosis since treated MCF-7 and MDA-MB-231 cells exhibited the morphological features of apoptosis [15] such as viability loss, cell shrinkage, cell detachment, and nuclear condensation in treated cells (Figure 2).

Treatment of MDA-MB-231 with RSF EtOAc resulted in a significant increase in levels of p53 (Figure 3), a key tumor suppressor/regulatory gene in apoptosis induction following DNA damage caused by anti-cancer agents [16,17], resulting in growth arrest of cells in G1 phase or apoptosis [18,19]. Furthermore, caspase-3/7 activities were examined by CellEvent caspase-3/7 green detection and confirmed the above results (Figure 4). Caspase 3/7 participate to the majority of steps which takes place during apoptosis. Here, activation caspase $3 / 7$ indicated that caspases act as key regulators in RSF EtOAc extract -induced apoptosis. Our results agree with the findings of Baschen et al. that ethanolic extracts of $R$. stricta induce apoptosis through upregulation of Bax proteins [10]. A recent study reported a similar effect [11] when evaluating crude alkaloid extracts of $R$. stricta leaves on human lung cancer cells A549. More than $90 \%$ of deaths from cancer occur due to metastasis of cancer cells, which remains one of the biggest challenges in cancer treatment [20,21]. Metastasis is considered the main cause of ineffectiveness of chemotherapeutic treatment and subsequent cancer deaths. However, prevention of metastasis improves chances of survival. Therefore, we examined the influence of plant extracts on the migratory capacity of the highly invasive MDA-MB-231 breast cancer cell line. The in vitro wound healing migration assay was used to survey the effects of selected extracts. Few studies have detailed anti-migration activity plant extracts. In this study, we showed for the first time that RSF EtOAc extracts have the ability to control MDA-MB-231 breast cancer cell migration at non-cytotoxic concentrations (Figure 5). To evaluate the mechanism of the anti-metastatic effect, we examined MMP-2 and MMP-9 gene expression. Previous reports showed that MMPs are important in facilitating tumor progression, metastasis, invasion, and angiogenesis [22,23]. Expression of metalloproteinase plays a vital role in invasion of malignant cancer cells into normal tissue and reduces effectiveness of chemotherapy. Therefore, inhibition of MMP expression is a useful strategy for controlling cell migration [24,25]. We focused on evaluating MMP-2/-9 expression because they degrade the main component of the basement membrane. Previous studies have found that certain natural products can inhibit cancer metastasis by inhibition of ECM degradation through inhibition of matrix metalloproteinase [26-30]. In the present study, we have demonstrated for the first time that RSF EtOAc extract displayed a remarkable ability to inhibit metastasis via down regulation of MMP-2 and MMP-9 in MDA-MB-231 breast cancer cells (Figure 6). Our data indicated that RSF EtOAc might be a promising candidate for 
restricting growth of breast cancer cells. However, with the discovery of new potential therapeutic agents, breast cancer models are needed for preclinical trials. Therefore, in vivo models of human breast cancer are an indispensable tool in the development of new cancer therapeutics. There are several techniques to induce mammary tumors in rats such as genetic engineering, xenograft models, and chemical methods. The chemical method using DMBA is considered the most common method for use in preclinical studies and is a useful tool for study of cancer [31]. Our study is the first to evaluate R. stricta extracts (RSF EtOAc) using an animal model. In this study, tumors were observed in the $8^{\text {th }}$ week, in agreement with studies that reported that DMBA administration to female rats caused primary breast tumors within 2 to 3 months [32,33]. The histopathology of the tissue examined revealed little improvement in the tissue when compared to control. The only improvement seen was reduction in necrotic areas of the studied tissue (Figure 8). However, this result did not agree with cell culture (in vitro) results, although cell culture methods are the most used in preclinical studies. This may be due to animal tissues (in vivo) having stromal and 3D structures, which are not present in cell culture models [34].

Several reports on GC-MS analyses of plant extracts revealed that most of the plant extracts contained some of the phytocompounds or analogs of the phytocompounds present in R. stricta. Camphor, which is found in Cinnamomum camphora [35] and some other plants [36], was one of the major components in R. stricta (Table 3). It was traditionally used as perfumes, cosmetics, Food flavorings, fumigants, household cleaners, and analgesics [37]. It shows several biological activities, such as antimicrobial, antiviral, antitussive, and analgesic activities [38]. Regarding its cytotoxic effects, Camphor has been reported to be active against several cancer cell lines, including human lung cancer (A549), colon adenocarcinoma (DLD-1), human keratinocytes (HaCaT), and Human skin fibroblasts (WS1) cell lines [36]. Another major phytochemical, namely D-allose (7.2\%) was also reported for its cytotoxic effects via inhibition of cancer cell growth [39]. Guanidine isolated from Polynesian Monanchora exhibited cytotoxic efficacy against human colorectal carcinoma (HCT116), promyelocytic leukemia (HL-60), and human lung normal (MRC5) cancer cells [40]. Moreover, aspidospermine and quebrachamine were reported to block the contractions of human prostatic tissue, cavernosum and guinea pig vas deferens and rabbit corpus spongiosum [41].

\section{Materials and Methods}

\subsection{Plant Sample Collection and Extract Preparation}

The fruits of R. stricta were collected from Riyadh, Saudi Arabia. The plant was identified by Dr. Jacob Thomas Pandalayil, Department of Botany and Microbiology, College of Science, King Saud University, and a voucher specimen (herbarium no. NATKSU-108) was deposited at the Department herbarium. R. stricta fruit were washed, dried, ground to powder, and sequentially extracted with solvents of decreasing lipophilicity ( $400 \mathrm{~mL}$ of $n$-hexane, chloroform, ethyl acetate, and methanol) using a Soxhlet extractor. The collected extracts were evaporated using a rotary evaporator under vacuum at $45^{\circ} \mathrm{C}$. The crude extracts were weighed and stored at $-80^{\circ} \mathrm{C}$ for further studies.

\subsection{Cytotoxicity Assays}

Determination of cytotoxicity (after a $48 \mathrm{~h}$ exposure period) was carried out by two following colorimetric methods.

\subsubsection{MTT Assay}

MCF-7 and MDA-MB-468 cells were cultured in DMEM (Gibco, ThermoFisher Scientific, CA, USA), and MCF-10A cells (were cultured in DMEM/F12 each containing 10\% v/v FBS. Cells were seeded into 24-well cell culture plates at a density of $5 \times 10^{4}$ cells per well in 1-mL aliquots of medium. Cells were permitted to attach for a period of $24 \mathrm{~h}$ at $37{ }^{\circ} \mathrm{C}$ and $5 \% \mathrm{CO}_{2}$ in an incubator. Cells were treated for $48 \mathrm{~h}$ with $R$. stricta fruit fractions and $100 \mu \mathrm{L}$ of MTT reagent (Invitrogen Life Technologies, CA, USA) 
( $5 \mathrm{mg} / \mathrm{mL}$ in PBS) was added to all wells. Plates were incubated at $37^{\circ} \mathrm{C}$ for $2-4 \mathrm{~h}$. One milliliter per well of isopropanol-HCL was added to dissolve crystalline formazan. Reduced MTT formation was measured at $540 \mathrm{~nm}$ using a microplate reader (Thermo Fisher Scientific, Waltham, MA, USA). Wells with untreated cells were considered as controls. For each extract tested, $\mathrm{IC}_{50}$ (concentration of tested compound needed to inhibit cell growth by $50 \%$ ) and cell viability was calculated using the following equation:

$$
\text { Cell Viability }(\%)=(\text { O.D of treated sample }) /(\text { O.D of untreated sample }) \times 100 \%
$$

\subsubsection{Lactate Dehydrogenase (LDH) Cytotoxicity Assay}

For each experiment, a fresh LDH mixture was prepared according to manufacturer instructions (LDH kit, Sigma-Aldrich, St. Louis, MO, USA). Cells were seeded in 24-well culture plates at a density of $5 \times 10^{4}$ cells/well and allowed to grow for $24 \mathrm{~h}$ before treatment. Cells were treated at $\mathrm{IC}_{50}$ for $48 \mathrm{~h}$. The supernatant $(100 \mu \mathrm{L})$ was transferred to a new 96 well plate and mixed with $100 \mu \mathrm{L}$ of LDH assay mixture. The reaction was incubated for $30 \mathrm{~min}$ at room temperature $\left(25^{\circ} \mathrm{C}\right)$ in the dark and analyzed using a microplate reader (Thermo Fisher Scientific) at $490 \mathrm{~nm}$. The cytotoxicity of each fraction was calculated:

$$
(\%)=(\text { O.D of treated sample }) /(\text { O.D of untreated sample }) \times 100 \%
$$

4.3. Assessment of Morphology of Apoptotic Cells by Phase-Contrast Inverted Microscopy, Fluorescent Hoechst 33,258 Staining, and Acridine Orange Ethidium Bromide Dual Staining

MDA-MB-231 cells were grown in 12-well plates and incubated for $48 \mathrm{~h}$ with and without RSF EtOAc extract at $\mathrm{IC}_{50}$. Morphological changes characteristic of apoptotic cells were observed using phase contrast inverted microscopy (MC-170 HD camera, Leica, Wetzlar, Germany) at 200× magnification. For Hoechst 33,258 staining, cells were treated then washed twice with PBS at room temperature, fixed with $4 \%$ paraformaldehyde, permeabilized using cold methanol, and stained with Hoechst 33,258 (Sigma) diluted in PBS (final concentration $0.5 \mu \mathrm{g} / \mathrm{mL}$ ) for $30 \mathrm{~min}$ in the dark. Cells were examined for nuclear changes (i.e., chromatin condensation and nuclear fragmentation) using a fluorescence microscope attached to an Axiocam 506 color camera (Zeiss, Wetzlar, Germany).

For acridine orange/ethidium bromide dual staining, MDA-MB-231 cells were treated at $\mathrm{IC}_{50}$ for $48 \mathrm{~h}$, directly stained with $\mathrm{AO} / \mathrm{EB}(4 \mu \mathrm{g} / \mathrm{mL})$ for $5 \mathrm{~min}$, and imaged immediately using fluorescence microscopy (EVOS, Carlsbad, CA, USA).

\subsection{Gene Expression Detection Using RT-PCR}

MDA-MB-231 cells $\left(5 \times 10^{4}\right.$ cells/well) were cultured in 6-well culture plates and treated with RSF EtOAc at $\mathrm{IC}_{50}$ for $24 \mathrm{~h}$. Following incubation, total RNA was prepared using TRIzol (TRI Reagent) (Invitrogen; Thermo Fisher Scientific, Inc., Carlsbad, CA, USA), and cDNA synthesized with oligo dt primer using superscript II reverse transcriptase cDNA synthesis Kit (Invitrogen; Thermo Fisher Scientific, Inc., Carlsbad, CA, USA) according to the manufacturer's instructions. PCR was performed using a Roter Gene machine, (QIAGEN, Hilden, Germany) with genes specific primers. Amplification products obtained by PCR were separated on $1.5 \%$ agarose gel, stained with ethidium bromide $(0.5 \mu \mathrm{g} / \mathrm{mL})$ and visualized under gel documentation system (Analytik Jena, Jena, Germany).

\subsection{Caspase 3/7 Green Fluorescence Detection}

MDA-MB-231 cells were seeded in 12-well culture plates at a density of $5 \times 10^{4}$ cells/well and allowed to grow for $24 \mathrm{~h}$ before treatment. After $\mathrm{IC}_{50}$ treatment with and without the extract, cells were labeled with caspase-3/7 green detection reagent $(5 \mu \mathrm{M})$ in DMEM medium in the dark at $37^{\circ} \mathrm{C}$ for $30 \mathrm{~min}$. Images were captured using fluorescence microscopy (EVOS, Carlsbad, CA, USA). 


\subsection{Scratch Wound Healing Migration Assay}

MDA-MB-231 cells were seeded onto a 12-well tissue culture plate and grown to $\sim 70-80 \%$ confluency. The monolayer was gently and slowly scratched with a sterile pipette tip $(10 \mu \mathrm{L})$ across the center of the well. Medium was aspirated and washed twice with PBS to remove the detached cells. Fresh medium was added. Non-cytotoxic concentrations (1/2 IC $\left.\mathrm{I}_{50}\right)$ of RSF EtOAc extract were added, and images were captured over several hours $(0 \mathrm{~h}, 24 \mathrm{~h}$ and $48 \mathrm{~h})$ to monitor closure or migration of cells to fill the scraped area using a phase contrast inverted microscope attached to a Leica MC-170 HD camera (Leica, Wetzlar, Germany). ImageJ software (NIH, Bethesda, MD, USA) was used to analyze the images. The relative migration ratio was calculated according to the following equation [42]:

Relative Migration Ratio $=($ Distance at $0 \mathrm{~h}$-Distance at $48 \mathrm{~h}) /($ Distance at $0 \mathrm{~h})$

\subsection{In Vivo Experimental Studies}

Thirty female Albino rats (115 \pm 15 g body weight, 49-59 days old) were obtained from the College of Pharmacy, King Saud University. The animals (five rats per cage) were housed in large cages at $25 \pm 2{ }^{\circ} \mathrm{C}$ with a $12 \mathrm{~h}$ light/dark cycle in the animal facility of the Zoology Department, College of Science. Rats had free access to water and commercial pelleted diet (Saudi Grains Organization, Riyadh, Saudi Arabia). All procedures in this study were performed according to the Animal Ethics Committee, King Saud University, Zoology Department (KSU/Animal Ethics Approval/2018/(03) (2448)).

Tumor Induction and Plant Extract Treatment

Rats were divided into three groups of five rats each: Normal control (group I) and groups II and III where carcinoma was induced in the breast with a single subcutaneous dose on the right side. Twenty five milligrams of 7,12-dimethylbenz(a)anthracene (DMBA) was dissolved in $1 \mathrm{~mL}$ of sunflower oil and administered to each rat [43]. Animals were observed daily for general health. When mammary tumors appeared, group II (DMBA control group) received $100 \mu \mathrm{L}$ of sunflower oil. Group III (DMBA + Extract) animals were injected with the extract (500 $\mu \mathrm{g}$ per rat, prepared in $100 \mu \mathrm{L}$ of sunflower oil) directly into the tumor every $48 \mathrm{~h}$ for two months [44,45]. At the end of the treatment period, rats were fasted overnight and sacrificed by cervical dislocation under anesthesia using diethyl ether. A caliper was used to measure the tumor size and tumor volume was calculated using $\mathrm{V}=0.5 \times\left(\mathrm{a}(\mathrm{b})^{2}\right)$ formula, where " $\mathrm{a}$ " and " $\mathrm{b}$ " are the major and minor diameters of tumors, respectively [32]. Removed tumors were washed in ice-cold PBS $(\mathrm{pH}=7.4)$ and weighed. Tumors were fixed in $10 \%$ buffered formalin solution and embedded in paraffin. The blocks were sectioned $(5 \mu \mathrm{m})$, and slides were prepared with hematoxylin-eosin stain and examined using a compound microscope.

\subsection{Determination of Total Phenolic, Flavonoid Contents}

Total phenolic content of all fractions were measured according to the Folin-Ciocalteu method [46], with slight modifications. Briefly, $12.5 \mu \mathrm{L}$ of extract $(1 \mathrm{mg} / \mathrm{mL}$ prepared in methanol) was mixed with $125 \mu \mathrm{L}$ of $25 \%$ Folin-Ciocalteu reagent in 96-well microplates and incubated for $5 \mathrm{~min}$. Following incubation, $12.5 \mu \mathrm{L}$ of $7 \% \mathrm{Na}_{2} \mathrm{CO}_{3}$ was added, and the plate was mixed and in the dark for $1.5 \mathrm{~h}$. Wells were read at $760 \mathrm{~nm}$ using microplate reader (Thermo Fisher Scientific, Waltham, MA, USA). Total phenolic content was quantified using a gallic acid standard curve. Total flavonoid content was calculated using aluminum chloride colorimetric assay [46]. In brief, $100 \mu \mathrm{L}$ of each crude extract $(1 \mathrm{mg} / \mathrm{mL})$ and $100 \mu \mathrm{L}$ of aluminum chloride $(2 \%)$ were mixed together in a 96-well plate. The plate was incubated for $10 \mathrm{~min}\left(25^{\circ} \mathrm{C}\right)$ and the absorbance was measured at $368 \mathrm{~nm}$. A calibration curve of quercetin, a standard flavonoid, was used for estimation of flavonoids in the samples. 


\subsection{Antioxidant Activity using DPPH Radical Scavenging Method}

The free radical scavenging activity of extracts was determined using 2,2-diphenyl-1-picrylhydrazyl (DPPH) [46]. Twenty microliters of each extract $(1 \mathrm{mg} / \mathrm{mL})$ was mixed with $80 \mu \mathrm{L}$ of a methanolic solution of DPPH $(100 \mathrm{mM})$ in 96 well plates. The plate was incubated in the dark for $30 \mathrm{~min}$ at $25^{\circ} \mathrm{C}$. Changes in absorption were read at $517 \mathrm{~nm}$ and radical scavenging activity was calculated by the following formula:

$$
\% \text { Scavenging }=\frac{\text { A517 Control }- \text { A517 Test }}{\text { A517 Control }} \times 100
$$

\subsection{Gas Chromatography-Mass Spectroscopy (GC-MS)}

GC-MS analysis was carried out using a Perkin Elmer Clarus 600 gas chromatograph/mass spectrometer (Turbomass, PerkinElmer, Inc., Waltham, MA, USA). An aliquot of $1 \mu \mathrm{L}$ of the RSF EtoAc fraction was injected into the Elite-5MS column $(30 \mathrm{~m}, 0.25 \mu \mathrm{m}$ thickness, $0.25 \mu \mathrm{m}$ internal diameter). The temperature programme started at $40{ }^{\circ} \mathrm{C}$, was held for $2 \mathrm{~min}$, then raised to $200{ }^{\circ} \mathrm{C}$ at a rate of $5{ }^{\circ} \mathrm{C}$ $\mathrm{min}^{-1}$ and held for $2 \mathrm{~min}$. From $200{ }^{\circ} \mathrm{C}$, the temperature was raised to $300^{\circ} \mathrm{C}$ at $5{ }^{\circ} \mathrm{C} \mathrm{min}^{-1}$ and held for $2 \mathrm{~min}$. The carrier (helium gas) flow was set at $1.0 \mathrm{~mL} \times \mathrm{min}^{-1}$. The results were compared by using the National Institute of Standard and Technology (NIST) and WILEY Spectral libraries.

\subsection{Statistical Analysis}

Statistical differences between control and treatment groups were analyzed using Student's $t$-test. Data are represented as the mean \pm S.D. All statistical analysis and charts were generated using Origin Lab software version 8 OriginPro 8.0 software (OriginLab®, Northampton, MA, USA). Cell migration data were analyzed with ImageJ imaging software (NIH, Bethesda, MD, USA).

\section{Conclusions}

The present study revealed that $R$. stricta contains variety of secondary metabolites that possess anticancer potential based on the assays carried out. Thus, our study proposes that fruit extract of $R$. stricta containing bioactive compounds may possibly be used as a therapeutical source for discovery of drugs to manage cancer diseases. The present study thus paves the way for additional research on the isolation and characterization of the active fraction(s) of $R$. stricta to increase its cytotoxicity and selectivity.

Author Contributions: N.A. and M.A.W. designed the study and wrote the manuscript; M.A., F.A.N. and N.A. carried out the cytotoxicity study, florescent microscopy, cell migration, and in vivo studies; M.A. performed qRT-PCR; O.M.N. performed phytochemicals analysis; A.S.A. performed GC/MS experiments; M.M. performed the histological studies.

Funding: Funding was provided by the Vice Deanship of Scientific Research Chairs. The funding bodies had no role in the study design, data collection and analysis, interpretation of data, or preparation of the manuscript.

Acknowledgments: The authors are grateful to the Deanship of Scientific Research, King Saud University for funding through Vice Deanship of Scientific Research Chairs.

Conflicts of Interest: The authors declare no conflict of interest.

\section{References}

1. Hutchinson, L. Breast cancer: Challenges, controversies, breakthroughs. Nat. Rev. Clin. Oncol. 2010, 7, 669-670. [CrossRef] [PubMed]

2. Ferlay, J.; Soerjomataram, I.; Dikshit, R.; Eser, S.; Mathers, C.; Rebelo, M.; Parkin, D.M.; Forman, D.; Bray, F. Cancer incidence and mortality worldwide: Sources, methods and major patterns in GLOBOCAN 2012. Int. J. Cancer 2015, 136, E359-E386. [CrossRef] [PubMed]

3. Al Diab, A.; Qureshi, S.; Al Saleh, K.A.; Al Qahtani, A.H.; Aleem, A.; Algamdi, M. Review on breast cancer in the Kingdom of Saudi Arabia. Middle-East J. Sci. Res. 2013, 14, 532-543. 
4. Al-Madouj, A.N.; Alshahrani, Z.S.; Alrawaji, A.I.; Hayder, M.S.; Al-Shridah, M.M.; Al-Shamrani, T.H. Cancer Incidence Report Saudi Arabia 2013; Saudi Cancer Registry: Riyadh, Saudi Arabia, 2016.

5. Zahreddine, H.; Borden, K.L. Mechanisms and insights into drug resistance in cancer. Front. Pharmacol. 2013, 4, 28. [CrossRef] [PubMed]

6. Moiseenko, F.; Volkov, N.; Bogdanov, A.; Dubina, M.; Moiseyenko, V. Resistance mechanisms to drug therapy in breast cancer and other solid tumors: An opinion. F1000Research 2017, 6, 288. [CrossRef] [PubMed]

7. Dias, D.A.; Urban, S.; Roessner, U. A historical overview of natural products in drug discovery. Metabolites 2012, 2, 303-336. [CrossRef]

8. Desai, A.G.; Qazi, G.N.; Ganju, R.K.; El-Tamer, M.; Singh, J.; Saxena, A.K.; Bedi, Y.S.; Taneja, S.C.; Bhat, H.K. Medicinal plants and cancer chemoprevention. Curr. Drug Metab. 2008, 9, 581-591. [CrossRef]

9. Ali, B.H.; Al-Qarawi, A.A.; Bashir, A.K.; Tanira, M.O. Phytochemistry, pharmacology and toxicity of Rhazya stricta Decne: A review. Phytother. Res. 2000, 14, 229-234. [CrossRef]

10. Baeshen, N.A.; Elkady, A.I.; Abuzinadah, O.A.; Mutwakil, M.H. Potential anticancer activity of the medicinal herb, Rhazya stricta, against human breast cancer. Afr. J. Biotechnol. 2012, 11, 8960-8972.

11. Elkady, A.I. Crude alkaloid extract of Rhazya stricta inhibits cell growth and sensitizes human lung cancer cells to cisplatin through induction of apoptosis. Genet. Mol. Biol. 2013, 36, 12-21. [CrossRef]

12. Elkady, A.I.; Hussein, R.A.; El-Assouli, S.M. Harmal extract induces apoptosis of HCT116 human colon cancer cells, mediated by inhibition of nuclear factor- $\mathrm{kB}$ and activator protein-1 signaling pathways and induction of cytoprotective genes. Asian Pac. J. Cancer Prev. 2016, 17, 1947-1959. [CrossRef] [PubMed]

13. Atale, N.; Gupta, S.; Yadav, U.C.; Rani, V. Cell-death assessment by fluorescent and nonfluorescent cytosolic and nuclear staining techniques. J. Microsc. 2014, 255, 7-19. [CrossRef] [PubMed]

14. Itharat, A.; Houghton, P.J.; Eno-Amooquaye, E.; Burke, P.J.; Sampson, J.H.; Raman, A. In vitro cytotoxic activity of Thai medicinal plants used traditionally to treat cancer. J. Ethnopharmacol. 2004, 90, 33-38. [CrossRef] [PubMed]

15. Van Cruchten, S.; Van Den Broeck, W. Morphological and biochemical aspects of apoptosis, oncosis and necrosis. Anat. Histol. Embryol. 2002, 31, 214-223. [CrossRef] [PubMed]

16. Oren, M. Regulation of the p53 tumor suppressor protein. J. Biol. Chem. 1999, 274, 36031-36034. [CrossRef]

17. Gasco, M.; Crook, T. p53 family members and chemoresistance in cancer: What we know and what we need to know. Drug Resist. Update 2003, 6, 323-328. [CrossRef]

18. Haupt, S.; Berger, M.; Goldberg, Z.; Haupt, Y. Apoptosis-The p53 network. J. Cell Sci. 2003, 116, 4077-4085. [CrossRef]

19. Hussain, S.P.; Harris, C.C. p53 biological network: At the crossroads of the cellular-stress response pathway and molecular carcinogenesis. J. Nippon Med. Sch. 2006, 73, 54-64. [CrossRef]

20. Steeg, P.S. Tumor metastasis: Mechanistic insights and clinical challenges. Nat. Med. 2006, 12, 895-904. [CrossRef]

21. Van Zijl, F.; Krupitza, G.; Mikulits, W. Initial steps of metastasis: Cell invasion and endothelial transmigration. Mutat. Res./Rev. Mutat. Res. 2011, 728, 23-34. [CrossRef]

22. Rowe, R.G.; Weiss, S.J. Navigating ECM barriers at the invasive front: The cancer cell-stroma interface. Annu. Rev. Cell Dev. Biol. 2009, 25, 567-595. [CrossRef]

23. Abba, M.; Patil, N.; Allgayer, H. MicroRNAs in the Regulation of MMPs and Metastasis. Cancers 2014, 6, 625-645. [CrossRef] [PubMed]

24. Kim, S.H.; Huang, C.Y.; Tsai, C.Y.; Lu, S.Y.; Chiu, C.C.; Fang, K. The aqueous extract of Prunella vulgaris suppresses cell invasion and migration in human liver cancer cells by attenuating matrix metalloproteinases. Am. J. Chin. Med. 2012, 40, 643-656. [CrossRef] [PubMed]

25. Kamijima, S.; Tobe, T.; Suyama, T.; Ueda, T.; Igarashi, T.; Ichikawa, T.; Ito, H. The prognostic value of p53, Ki-67 and matrix metalloproteinases MMP-2 and MMP-9 in transitional cell carcinoma of the renal pelvis and ureter. Int. J. Urol. 2005, 12, 941-947. [CrossRef] [PubMed]

26. Lee, H.S.; Na, M.H.; Kim, W.K. Alpha-Lipoic acid reduces matrix metalloproteinase activity in MDA-MB-231 human breast cancer cells. Nutr. Res. 2010, 30, 403-409. [CrossRef]

27. Al Dhaheri, Y.; Attoub, S.; Arafat, K.; Abuqamar, S.; Viallet, J.; Saleh, A.; Al Agha, H.; Eid, A.; Iratni, R. Anti-metastatic and anti-tumor growth effects of Origanum majorana on highly metastatic human breast cancer cells: Inhibition of NFkappaB signaling and reduction of nitric oxide production. PLoS ONE 2013, 8, e68808. [CrossRef]

28. Do Thi, N.; Hwang, E.S. Effects of laver extracts on adhesion, invasion, and migration in SK-Hep1 human hepatoma cancer cells. Biosci. Biotechnol. Biochem. 2014, 78, 1044-1051. [CrossRef] 
29. Zheng, L.; Zhang, Y.M.; Zhan, Y.Z.; Liu, C.X. Momordica cochinchinensis seed extracts suppress migration and invasion of human breast cancer ZR-75-30 cells via down-regulating MMP-2 and MMP-9. Asian Pac. J. Cancer Prev. 2014, 15, 1105-1110. [CrossRef]

30. Pei, S.; Yang, X.; Wang, H.; Zhang, H.; Zhou, B.; Zhang, D.; Lin, D. Plantamajoside, a potential anti-tumor herbal medicine inhibits breast cancer growth and pulmonary metastasis by decreasing the activity of matrix metalloproteinase-9 and -2. BMC Cancer 2015, 15, 965. [CrossRef]

31. Russo, J.; Russo, I.H. Experimentally induced mammary tumors in rats. Breast Cancer Res. Treat. 1996, 39, 7-20. [CrossRef]

32. Al-Saeedi, F.J. Study of the cytotoxicity of asiaticoside on rats and tumour cells. BMC Cancer 2014, 14, 220. [CrossRef] [PubMed]

33. Shoja, M.H.; Reddy, N.D.; Nayak, P.G.; Biswas, S.; Srinivasan, K.K.; Rao, C.M. In vitro mechanistic and in vivo anti-tumor studies of Glycosmis pentaphylla (Retz.) DC against breast cancer. J. Ethnopharmacol. 2016, 186, 159-168. [CrossRef] [PubMed]

34. Kim, J.B.; O'Hare, M.J.; Stein, R. Models of breast cancer: Is merging human and animal models the future? Breast Cancer Res. 2004, 6, 22-30. [CrossRef] [PubMed]

35. Stubbs, B.J.; Specht, A.; Brushett, D. The essential oil of Cinnamomum camphora (L.) Nees and Eberm.-variation in oil composition throughout the tree in two chemotypes from Eastern Australia. J. Essent. Oil Res. 2004, 16, 9-14. [CrossRef]

36. Cote, H.; Boucher, M.A.; Pichette, A.; Legault, J. Anti-Inflammatory, Antioxidant, Antibiotic, and Cytotoxic Activities of Tanacetum vulgare L. Essential Oil and Its Constituents. Medicines 2017, 4, 34. [CrossRef] [PubMed]

37. Chen, W.; Vermaak, I.; Viljoen, A. Camphor-A fumigant during the Black Death and a coveted fragrant wood in ancient Egypt and Babylon-A review. Molecules 2013, 18, 5434. [CrossRef] [PubMed]

38. Sokolova, A.S.; Yarovaya, C.O.; Shernyukov, C.A.; Pokrovsky, C.E.; Pokrovsky, C.A.; Lavrinenko, V.A.; Zarubaev, V.V.; Tretiak, T.S.; Anfimov, P.M.; Kiselev, O.I.; et al. New quaternary ammonium camphor derivatives and their antiviral activity, genotoxic effects and cytotoxicity. Bioorg. Med. Chem. 2013, 21, 6690-6698. [CrossRef]

39. Noguchi, C.; Kamitori, K.; Hossain, A.; Hoshikawa, H.; Katagi, A.; Dong, Y.; Sui, L.; Tokuda, M.; Yamaguchi, F. D-Allose Inhibits Cancer Cell Growth by Reducing GLUT1 Expression. Tohoku J. Exp. Med. 2016, 238, 131-141. [CrossRef]

40. El-Demerdash, A.; Moriou, C.; Martin, M.T.; Petek, S.; Debitus, C.; Al-Mourabit, A. Unguiculins A-C: Cytotoxic bis-guanidine alkaloids from the French Polynesian sponge, Monanchora n. sp. Nat. Prod. Res. 2018, 32, 1512-1517. [CrossRef]

41. Deutsch, H.F.; Evenson, M.A.; Drescher, P.; Sparwasser, C.; Madsen, P.O. Isolation and biological activity of aspidospermine and quebrachamine from an Aspidosperma tree source. J. Pharm. Biomed. Anal. 1994, 12, 1283-1287. [CrossRef]

42. Luanpitpong, S.; Talbott, S.J.; Rojanasakul, Y.; Nimmannit, U.; Pongrakhananon, V.; Wang, L.; Chanvorachote, P. Regulation of lung cancer cell migration and invasion by reactive oxygen species and caveolin-1. J. Biol. Chem. 2010, 285, 38832-38840. [CrossRef] [PubMed]

43. Tuncer, E.; Unver-Saraydin, S.; Tepe, B.; Karadayi, S.; Ozer, H.; Sen, M.; Karadayi, K.; Inan, D.; Elagoz, S.; Polat, Z. Antitumor effects of Origanum acutidens extracts on human breast cancer. J. Balk. Union Oncol. 2013, 18, 77-85.

44. Abdelmajidzyad, Z.; Morizet, J.; Legres, L.; Benard, J.; Chouaib, S. In vivo effect of the combination of TNF and adriamycin against a human breast cell line expressing the MDR-phenotype. Int. J. Oncol. 1995, 7, 1067-1072.

45. Ait Mbarek, L.; Ait Mouse, H.; Elabbadi, N.; Bensalah, M.; Gamouh, A.; Aboufatima, R.; Benharref, A.; Chait, A.; Kamal, M.; Dalal, A. Anti-tumor properties of blackseed (Nigella sativa L.) extracts. Braz. J. Med. Biol. Res. 2007, 40, 839-847. [CrossRef] [PubMed]

46. Ghosh, S.; Derle, A.; Ahire, M.; More, P.; Jagtap, S.; Phadatare, S.D.; Patil, A.B.; Jabgunde, A.M.; Sharma, G.K.; Shinde, V.S.; et al. Phytochemical analysis and free radical scavenging activity of medicinal plants Gnidia glauca and Dioscorea bulbifera. PLoS ONE 2013, 8, e82529. [CrossRef] [PubMed]

Sample Availability: Samples of the extracts and fractions are available from the authors. 